\title{
EXPLORING CONTEXTUAL CHARACTERISTICS OF TRADITIONAL MEDINAS IN NORTH AFRICA
}

\author{
Huyam H. Abudib \\ University of Strathclyde, Glasgow \\ huyam.abudib@strath.ac.uk
}

\begin{abstract}
In an age of globalization and standardization, cities around the world are losing their historical and cultural identity. Traditional cities of the Muslim world, in particular, are witnessing an increased transformation in their urban fabric, which is extremely different from their original one, and not necessarily better. This paper explores the historical precedents of three traditional medinas in North Africa, which are Tripoli, Tunis and Fez, from a comparative perspective. The aim of this study is to analyse key contextual characteristics of these cities in an attempt to derive key principles that are capable of improving the contemporary built environment and safeguarding the cultural identity of traditional medinas. The paper concludes with a number of lessons learned from the visual form, urban pattern and land-use of traditional medinas, and sets out challenges that face decision makers and designers in manifesting the essence of traditional medinas in contemporary urban form.
\end{abstract}

Keywords: Traditional Medinas; Contextual Characteristics; Urban Pattern

\section{INTRODUCTION}

Since the mid-20th century many cities in North Africa, and elsewhere in the Muslim world, have witnessed increasing implementation of contemporary urban projects due to rapid economic growth and associated increase in population. Many countries sought quick urban housing solutions and consequently implemented foreign strategies and models in the new urban developments. The newly-adopted strategies were completely different from the original morphological pattern of traditional cities, and seldom had any regard for their historical and social context. In his book, 'The Failure of Modern Architecture', Brolin (1976) states that the ideology of modern architecture mostly deals with the way people should live, rather than the way they do live. In the contemporary, so-called 'Modern' housing types, courtyard houses along with their concepts and formal elements were forgotten and replaced by new types, usually in the form of linear apartment buildings, tower blocks or suburban villas.

Traditional cities of the Muslim world are an endless motivation for research projects. This study explores three traditional medinas in the region of North Africa. The main objective is to derive principles from historical precedents, in order to improve the quality of contemporary built environment, and to develop a framework that allows cultural identity to be clearly reflected in contemporary architecture and the overall built environment. Whereas the exploration of traditional built environment usually involves two aspects; social and physical context, social context is not the focus of this paper, which focuses on the physical aspects of traditional cities, and explores contextual characteristics of three major traditional medinas in term of their visual form, urban fabric and land use.

There is no single accepted definition of the term 'North Africa'. The region is defined by some as the area expanding north of the Sahara from the Red Sea on the east to the Atlantic Ocean on the west. However, this area is more commonly referred to as Northern Africa. Others refer the term to the area known by the French during colonial times as Afrique $d u$ Nord, which covers modern Morocco, Algeria and Tunisia. The most common accepted definition, and the 
one used in this study, is the area expanding from the western border of Egypt in the east to the Atlantic shores of Morocco in the west, which includes the coastal plain of Libya, Tunisia, Algeria and Morocco (Warmington, 2015).

The three traditional medinas explored in this study are; Tripoli, Tunis and Fez. The old medina of Tripoli is chosen because of its historical and regional importance as the capital of Libya, in addition to its special importance to the researcher. The old medina of Tunis is chosen because it is the capital of Tunisia and one of few cities that are listed as world heritage sites. The old medina of Fez is chosen in this study for various reasons. Although it is not the current capital of the country; it was the capital of Morocco three times during its twelve-hundred-year history and it is the oldest of the four imperial cities of Morocco: Fez, Meknes, Marrakesh and Rabat. In addition, Fez is known to have the best preserved old city in the Arab world and it stands out as the world's largest urban area with no car traffic.

This study is divided into three sections. The first looks at the natural setting for each city and traces its historical formation and development; the second explores the contextual characteristics of the three cities through analysing the visual form, urban pattern and land use of these cities; the third section reaches conclusions on the key qualities that can contribute to creating better contemporary built environment that clearly reflects the cultural identities of these cities. The methodology applied in this study is based on case studies and a mixed-method approach, where case studies are defined by an interest in the chosen cases rather than the investigation technique used (Stake, 1998). The required information is gathered through maps, photos, historical documentations and previous studies, and investigated through comparative analysis.

\section{NATURAL SETTING AND HISTORICAL DEVELOPMENT:}

This section introduces the three cities of Tripoli, Tunis and Fez by looking at their natural setting and historical development. This is believed necessary in order to visualize the urban pattern and understand the contextual characteristics of these cities.

\section{Natural Setting:}

Tripoli and Tunis are both coastal cities, while Fez is further inland. However, the three cities benefit from being on major routes that connect different regions and even different continents together. This brought the cities great importance, seen by the different civilizations that recognised this and fought hard to control them. The city of Fez further benefits from its natural water sources. Apart from the river and its tributaries that were easily canalised and turned to urban use, the city contains numerous water springs. All three cities benefit from pleasant climate, despite their different locations and topography. Their populations are similar. Yet, it is important to note that the population in this paper refers to the people who live in the whole city and not just the traditional. Table 1 shows these similarities in brief.

Tripoli is located on the northwest side of Libya $32^{\circ} 54^{\prime} \mathrm{N} 13^{\circ} 11^{\prime} \mathrm{E}$, along the coast on a rocky headland that projects into the sea forming a natural bay. Having a central location on the southern coast of the Mediterranean, Tripoli served through history as a connection point between Europe and the sub-Saharan region. As a matter of fact, due to the direction of the prevailing wind in North Africa and the difficulty in navigating across it, the main sea route was usually between Tripoli and southern Europe, rather than between Tripoli and Cyrenaica. Based on the census of 2004 the population of Tripoli is around 1.065 million. It benefits from a Mediterranean climate, which makes it hot/dry in summer and cold/rainy in winter. Temperature ranges between $36^{\circ} \mathrm{C}$ in summer and $7^{\circ} \mathrm{C}$ in winter.

Tunis is located in the north-eastern part of Tunisia, $36^{\circ} 50^{\prime} \mathrm{N}, 10^{\circ} 13^{\prime} \mathrm{E}$, on the Gulf of Tunis, behind the lake of Tunis and the port of Halaq al Wadi. The city of Tunis is always connected to the more powerful and ancient city of Carthage, which was the capital of the Archnet-IJAR, Volume 10 - Issue 1 - March 2016 - (325-343) - Regular Section 
Carthaginian Empire and one of the most important cities of the Roman Empire. Although both cities are located at the intersection of natural routes serving the diverse regions of the country not very far from each other, Carthage was founded on the coast by the Phoenicians, while Tunis was constructed back from the coast on the landward side of the lagoon by the Arab-Muslims. According to the 2014 population Survey, the city has a population of 1.056 million inhabitants. It has a Mediterranean climate that makes it hot/dry in summer and cold/rainy in winter. Temperature ranges between $34^{\circ} \mathrm{C}$ in summer and $8^{\circ} \mathrm{C}$ in winter.

Fez is located in the west-central part of Morocco, $33^{\circ} 58^{\prime} \mathrm{N} 04^{\circ} 59^{\prime} \mathrm{W}$, on the banks of Wadi Fez and surrounded by low hills. It has a central geographical location, with regard not only to different regions of Morocco, but also to the whole of North Africa. It lies on the easiest route between the Rif and Middle Atlas Mountains and is situated at the intersection point of two great communication axes: the first is north-south between the Mediterranean and the Sub-Saharan region, and the second is west-east between the Atlantic coast and central North Africa. This unique location gives the city of Fez a special importance politically, economically and culturally that was realized by the different dynasties that ruled it. According to the 2014 Census, the city has a population of 1.8 million. It has a tropical climate that makes it hot/dry in summer and cold/rainy in winter. Temperature ranges between $35^{\circ} \mathrm{C}$ in summer and $4^{\circ} \mathrm{C}$ in winter.

Table 1: Natural Setting (Source: Author, 2015).

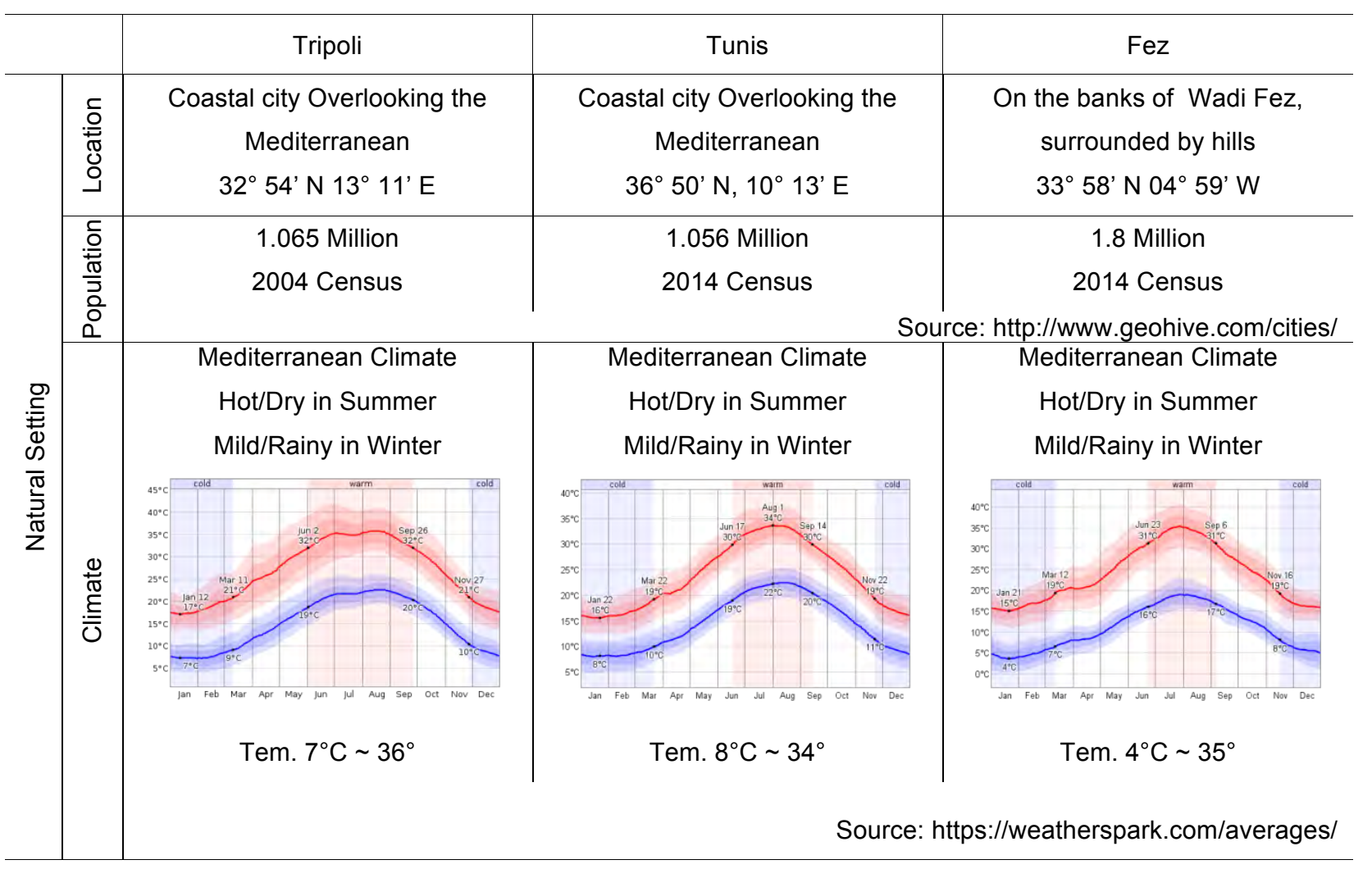

\section{Historical Development:}

The cities of Tripoli, Tunis and Fez have long histories, as various civilizations occupied the cities and added their own footprints to them. The origin of Tripoli and Tunis is believed to be Phoenician, dating back to the 1st and 4th century BC. After the formation of the Carthaginian

Archnet-IJAR, Volume 10 - Issue 1 - March 2016 - (325-343) - Regular Section 
Empire, Tripolitania, with its three cities, and Tunis became part of this empire. In the 3rd and 2nd centuries BC Carthage was weakened, and after a three-year siege the city was destroyed in $146 B C$ by the Romans, and its site ceremonially crushed. Tripolitania and Tunis, along with other Carthaginian settlements, became Roman protectorates. Tripoli flourished during Roman rule, especially when Septimus Severus, a native of Tripolitania from Leptis, became emperor of Rome (Metz, 2004). However, the Romans were more interested in reconstructing and developing Carthage rather than Tunis.

The most significant historical and cultural change in the cities of North Africa occurred during the 650s, when the Muslim Arabs came to North Africa, bringing with them a religion, a culture, a language and a certain pattern of living, which created the region's enduring character (Wright, 1969). The two cities of Tripoli and Tunis were developed, and the city of Fez was established during this Era. Under Islamic rule, Tripoli became an increasingly important centre for the trans-Saharan caravan trade, and attracted foreign interest in the city. Tunis, on the other hand, was established around 698 as a Muslim marine arsenal, where troops were living on a permanent basis ready to oppose any enemy landing on the coast, or to raid the coast of southern Europe (McGuinness, 1992).

Fez was the latest of the three cities to be established. Although historians are unsure of the exact date of its foundation, the history of Fez is believed to have started in 789, when Idris I founded the first nucleus of the town on the right bank of the Oued River (Bosworth, 2010). However, Idris I died before he had time to develop it. Twenty years after his death, his son Idris $I I$, is believed to have established a second town on the left bank, giving the city its final form, making him regarded as the true founder of the city of Fez.

During that time the city of Fez was two [distinct] towns located on both sides of the river; each constructed in a different era and each surrounded by walls that were flanked by several towers. For several centuries the two cities co-existed and developed until Al-Moravids combined the towns into one in 1070, and transformed it into a strong military base. During Al-Moravids dynasty, Fez experienced an era of development and prosperity. Bridges were constructed to bring the two sides together and new neighbourhoods and military buildings were built. AlMoravids ruler, Youssef Ibn Tachfin, constructed a single wall around both cities to further combine them into one. Al-Moravids also reconstructed the Qarawiyyin mosque, a medium-size mosque built in 859 , and changed it into a great mosque of vast dimensions and astonishing Andalusian ornamentation. Al-Moravids are seen by some historians as the second founders of Fez.

The three cities, Tripoli, Tunis and Fez, fell into the hands of Al-Mohads, who between 1152 and 1160 succeeded in unifying the entire region of North Africa under one central indigenous authority for the first and last time in its history (McKenna, 2011). Despite the great achievements of Al-Mohads in Tunis and particularly in Fez, their ruling period in Tripoli did little for the development of the city. By 1453 North Africa was divided into three different Muslim states, each ruled by a different Berber dynasty: The Hafsids controlling Tripolitania, Tunisia and eastern Algeria, The Zayyanids ruling most of western Algeria, and the Marinids ruling over Morocco.

The Hafsids period is considered by historians as the most essential period in the history of Tunis, when the city reached the limits of its stability and prosperity. During their dynasty the original urban core of the city was extended by the construction of two suburbs that were protected by the ramparts. It is stated by Habib Saidi (2011) that Tunis only became capital when the Hafsids who, for the first time in the history of the country, dared to take away the central power from Kairouan. The Kasbah, inherited from Al-Mohads, became the seat of the new dynasty; a new arsenal was constructed to the east of the town, the Al-Zaitouna mosque was enlarged, and new city gates and towers were added (Bosworth, 2010). 
By 1520 the Ottomans, who occupied Egypt in 1517, became involved in the fighting between Muslims and Christians in North Africa. The Ottoman rule in North Africa, excluding Morocco, began when locals in the region requested the help of the Ottomans, the strongest Muslim empire at the time, against the Christians of the Iberian Peninsula. At first, the region was ruled by different governors sent from Istanbul, but one by one the cities of North Africa became independent from the Ottoman government, yet retained strong ties with the Ottoman Sultan by recognizing him as Caliph.

During the 159 years of the first Ottoman rule the city of Tripoli expanded and emerged as a real urban centre in North Africa. This urban growth continued during the Karamanli rule (1710 1835). New hammams, private houses and shops were set to accommodate the growing population. In 1835 the Ottomans resumed direct rule of Tripolitania in an attempt to forestall the French expansion in North Africa. The first period of their rule (1835 1862) was characterised by great instability, due to a series of rebellions by the locals. However, during the second period (1863 1911) the Ottoman governors introduced serious urban and economic measures to improve the living conditions of the locals, who had suffered great neglect by the previous Ottoman authority. Among the social, economic and urban schemes was the establishment of educational buildings, such as primary and secondary schools, a military college, an Islamic Schools for arts and crafts, and an industrial training school. A new court and a hospital were constructed, and the castle and city walls repaired during this period.

By 1920 all of North Africa was under European colonial control. After invading Algeria in 1830 the French invaded Tunisia in 1881 and proposed a treaty of protection to Sadok Bey of Tunis the same year. Under this treaty the French preserved the administration of the Bey of Tunis, yet applied an indirect form of rule, which they later applied to Morocco as well. The French conquest of Morocco started in 1911, when Moroccan forces besieged the Frenchoccupied city of Fez. After the French troops brought the siege to an end they forced Abdelhafid of Morocco to sign the Treaty of Fez, which formally put Morocco under the French protection and allowed them to divide the country with the Spanish. The seizure of Morocco coincided with the conquest of Libya, which was similarly invaded in 1911 by the Italians. A year later the Ottomans surrendered, and made peace with Italy. However, the locals rejected the treaty between the Italians and the Ottomans, and denied the Italian control of the country. Copying France's terrible acts of repression in Algeria, the Italians only managed to turn Libya into an Italian colony after over twenty years of resistance.

During the colonial powers, the three cities were subjected to similar colonial strategies, when new colonial cities were constructed beside the existing traditional ones. Yet, it is fair to say that the French approach in maintaining the traditional cities of Fez and Tunis was much more effective than that of the Italians. In Tripoli, connecting roads were added to the existing routes that emerged from the castle to create the new street network. These connecting roads were compared by Lugi Luiggi, the designer of the master plan, to the Ring in Vienna, the Boulevards of Paris, and the Crescents in London (McLaren, 2006). The Italians did not make any detailed program to preserve the old Medina. Their main focus was to simply strengthen whatever was already standing, and to support the city just enough so that it would require the least investment possible.

In Tunis, a new colonial city with methodical planning, straight lines, chequered patterns and modern buildings started to emerge alongside the ancient city, which was partly deprived of its administrative and commercial functions. Major transformation took place in the old medina in order to create the necessary connections between the two cities. The major undertaking, with no doubt, was the planning of a ring boulevard around the medina, replacing the walls of the city (Saidi, 2011). In Fez, following the Treaty of Fez and the arrival of more French in Morocco, a new French-style 'Ville Nouvelle' was constructed. Yet, due to the traditional city's topography, 
the new colonial city was sited two kilometres west of the ancient city, allowing the traditional medina to develop independently and operate in its traditional manner.

\section{A FRAMEWORK OF ANALYSING CONTEXTUAL CHARACTERISTICS OF THE THREE CITIES}

This section explores the contextual characteristics of Tripoli, Tunis and Fez, by looking at each city's visual form, urban pattern and land use. These three characteristics are believed to be clear indicators of each city's historical precedents, and consequently essential in concluding key principles capable of improving the contemporary built environment and safeguarding the cultural identity of traditional medinas.

\section{Tripoli:}

In an article that was published in Saudi ARAMCO World, Charles O Cecil describes Tripoli as the Crossroad of Rome and Islam. This is strongly reflected in the urban pattern that makes it a typical Muslim city, with a clear Roman history.
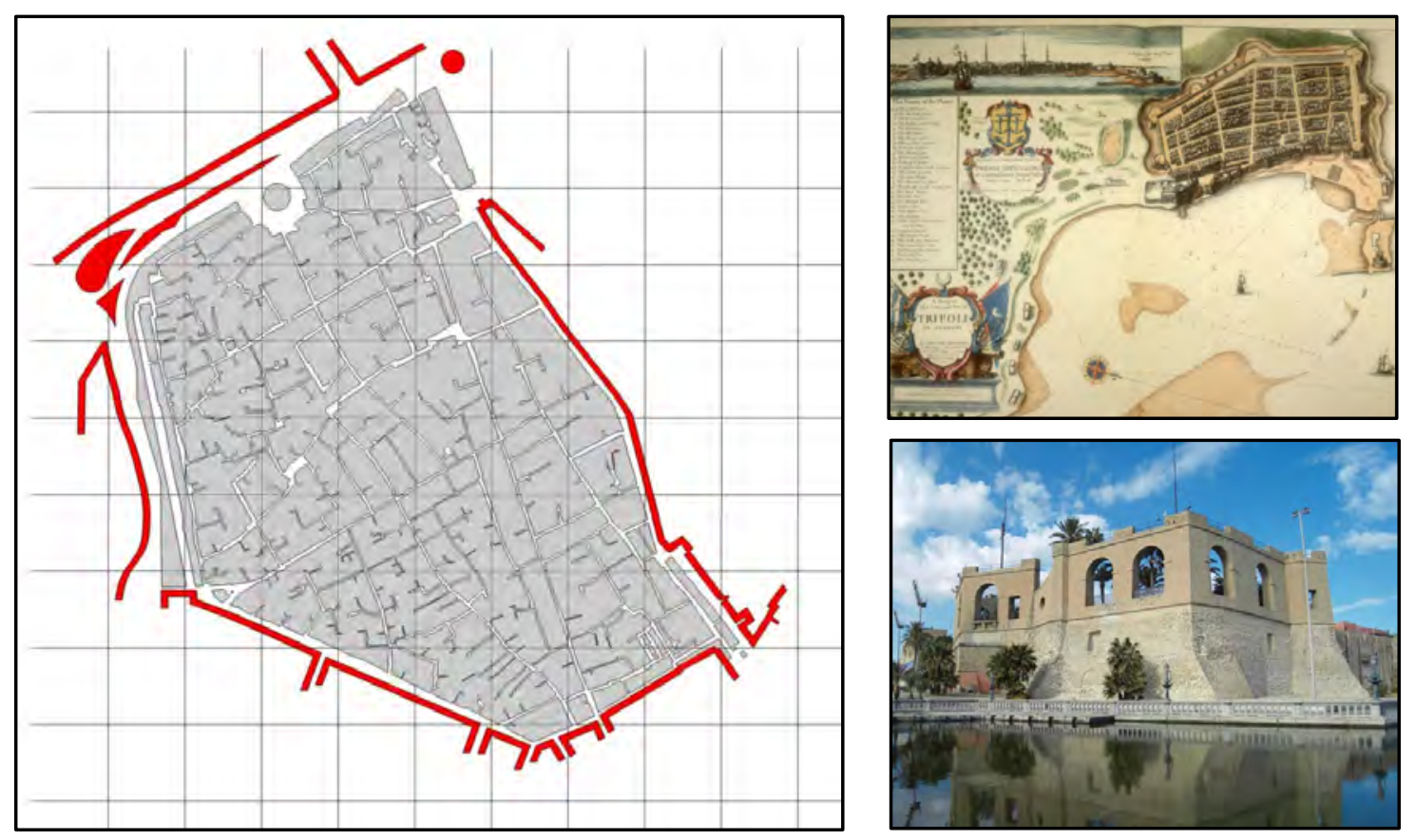

Figure 1. (Left) Tripoli general layout (Source: Author, 2015); (Top Right) The city \& port of Tripoli (Source: Seller, 1675); (Bottom Right) Al Saraya Al Hamra (Source: www.milosaleem.wordpress.com)

The urban fabric of the city has witnessed the passage of several civilizations over time. Each civilization has left a mark on the city's physical characteristics, with the exception of Vandal and Spanish rule, when the city experienced great destruction (Remali et al, 2015). In describing the city Pedro Navarro, who was a Spanish military engineer and general during the 15th 16th century, states that the city is larger than I thought, and although those who admired it spoke well about it, I can see that they were saying only half the truth; and among all the cities I have seen in the world, I do not find any that is comparable to it (citied in Micara, 2008, p387). Today, Tripoli's visual form is dominated by its castle and the remains of its walls, its compact courtyard houses and narrow alleys. The old medina of Tripoli has a pentagonal form and is surrounded by strong masonry walls. It is divided into five residential quarters, where each quarter is made up of 
clusters of households based on social ties, common interests and shared moral unity (Eilelman, 1981). It is stated by Ludovico Micara (2008) that the city of Tripoli reflects clearly the orthogonal street grid of the classic Roman layout, which is based on cardo and decumanus, and the irregular and curvilinear passages of the Arab-Muslim city, along with its cul-de-sacs.

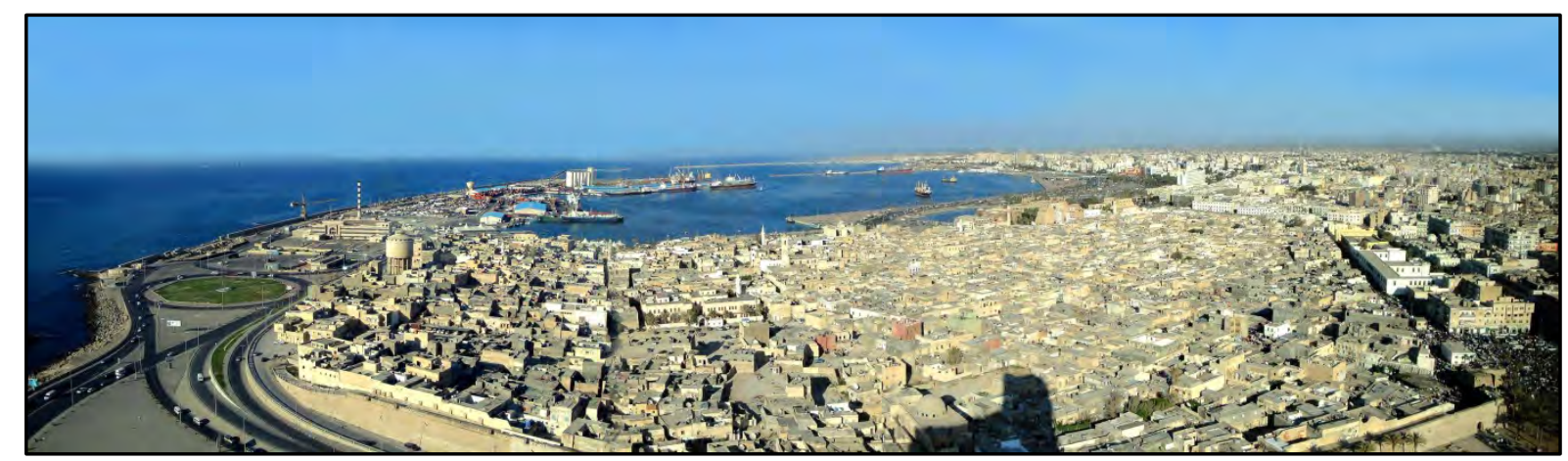

Figure 2. An overview of traditional medina of Tripoli (Source: www.fayeandsteve.com, 2015).

The original Roman street network of the traditional city of Tripoli consists of the cardo, which runs parallel to the coast from southeast to northeast, and two major decumani, which run from southwest to northeast, leading to the port. The intersection between the cardo and the northern decumanus was marked by a Tetrapylon of Marcus Aurelius, constructed in 163 AD. During the Roman period, sea trade played a major role in the city's life. In addition to being on an intersection of trade routes between the sea and the hinterland, the location of the city provided the Romans with a deep harbour that was well protected by a promontory to the northeast, and guarded by a low hill to the west.
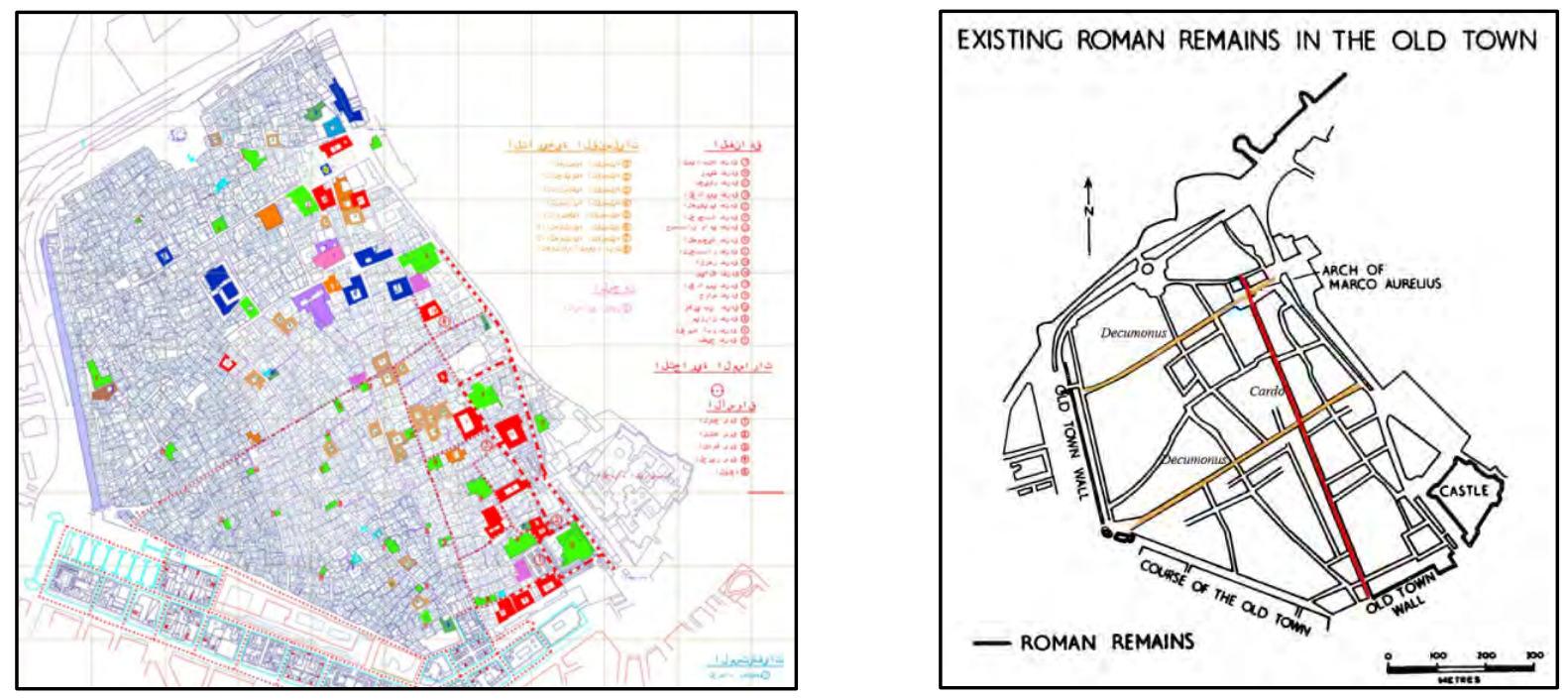

Figure 3. (Left) Land-use in traditional medina of Tripoli (Source: Historic Cities Administration Tripoli, 2013); (Right) Historical Roman layout (Source: Author, 2015).

With the Arab-Muslim arrival in 642 AD the street network started to follow irregular patterns, which is a typical character of many Arab-Muslim cities. During this period the city focused more on its connection with its hinterland than with the sea. The western part of the medina is believed

Archnet-IJAR, Volume 10 - Issue 1 - March 2016 - (325-343) - Regular Section 
to have developed during this period. As for the street network, the intersection between the cardo and the southern decumanus became the new public centre. It was marked by the remains of four beautiful Roman columns situated on the corners of the crossing, and was known as Arba'a Arsat, meaning 'the four columns'. For this reason it is fair to say that the Roman cardo and decumani had, and still have, a strong role in the street network of the old medina, as their intersections contain the main public centres of both the Roman and the Arab-Muslim city. Like other Islamic cities, the traditional medina of Tripoli is famous for its compact structure, courtyard houses and narrow lanes with flying buttresses between the opposite walls of the street facades. As the Arab city grew, the urban plots became large complex shapes and no longer corresponded to the standard measures of Roman cities. Numerous cul-de-sacs started to emerge in the street network, in order to penetrate into the large urban plots and reach their internal areas. Courtyard houses, in a range of sizes became the main components of the city's urban structure.

The commercial centre of the city is mainly located in the south and southeast of the medina. Different suqs (markets), such as Suq at-Turk and Suq Er-Rba, together with some workshops, are located close to each other giving shoppers easy access from one market to another. A number of Hammams (Turkish baths) and funduqs are mostly located in the eastern sector of the city along the main arteries of the Roman grid (Sibley \& Fadli, 2008). Small mosques along with Koranic schools, small shops and bakeries are well distributed throughout the residential quarters. Large mosques, mostly built by ottoman governors, are located in the eastern part of the medina.

It is interesting to note that, unlike traditional Arab-Muslim cities, there is no central mosque in the traditional medina of Tripoli, despite the great number of both small and large mosques located within the city walls. It is stated by At-Tijani in his Rihlah to Tripoli in the years 1306-1308 that it was a flourishing city, where the mosques were so numerous that they exceeded the number of the houses ( in Micara, 2013, p74). However, a number of great mosques described by At-Tijani no longer exist, as all traces of Arab-Muslim existence before the Ottomans were completely destroyed by the Spanish and Maltese knights of Saint John. Ludovico Micara (2013, p51) states that in the case of Tripoli the disastrous Spanish occupation and the resulting urban decay that affected the city for a period of about forty years (1510 1551) strongly modified the urban topography, deleting important traces of its ancient past. The real reason behind the absence of a central mosque in the traditional medina of Tripoli may not be known but, nevertheless, the city's Islamic characteristics can never be denied.

\section{Tunis:}

The traditional city of Tunis was originally a walled city overlooking the Mediterranean. The city walls were demolished during the French colonization and were replaced by a ring road. Today a few portions of the wall exist as free standing monuments, mainly representing the gates of a great Arab-Islamic city, as is that which used to be the eastern gate of the old medina.

The city of Tunis is famous of Al-Zaitouna mosque, constructed at the end of the 9th century by Abu Ibrahim Ahmad. The great mosque with its minaret and domes dominates the city's skyline, along with other smaller mosques distributed throughout the city. The street network of the traditional medina of Tunis is based on two sets of principal routes. The first one leads from each gate of the city to the great mosque, located in the centre; the second from one gate to another (Amodei, 1985). Although the city walls, along with some gates, were demolished, the importance of this street network is still evident today. The main streets of the medina create large urban blocks, which are further divided into residential clusters through connecting streets and cul-de-sacs. 


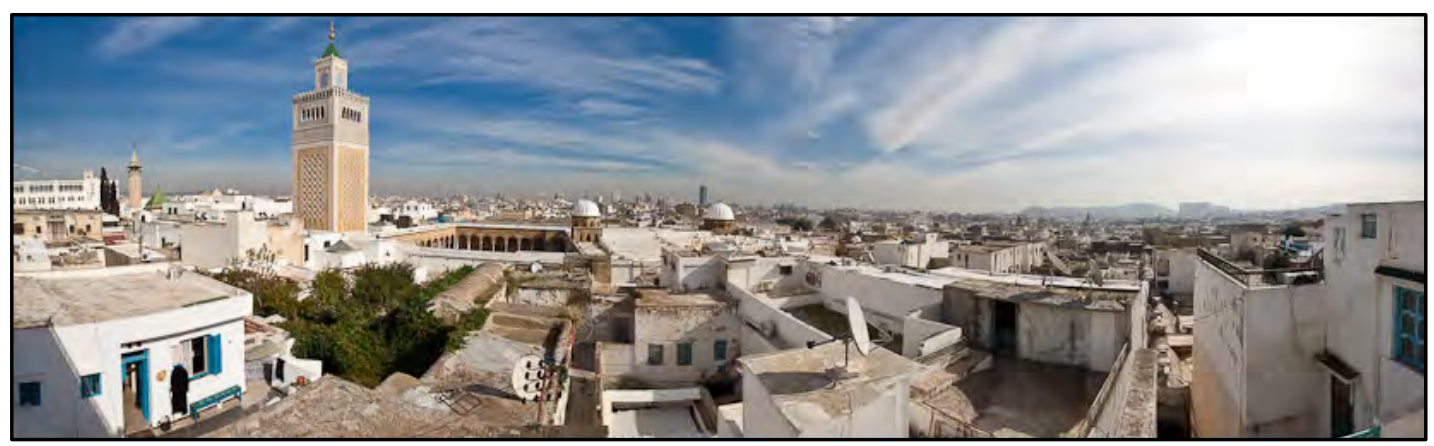

Figure 4. An overview of traditional medina of Tunis (Source: www.mornarius.wordpress.com, 2015).
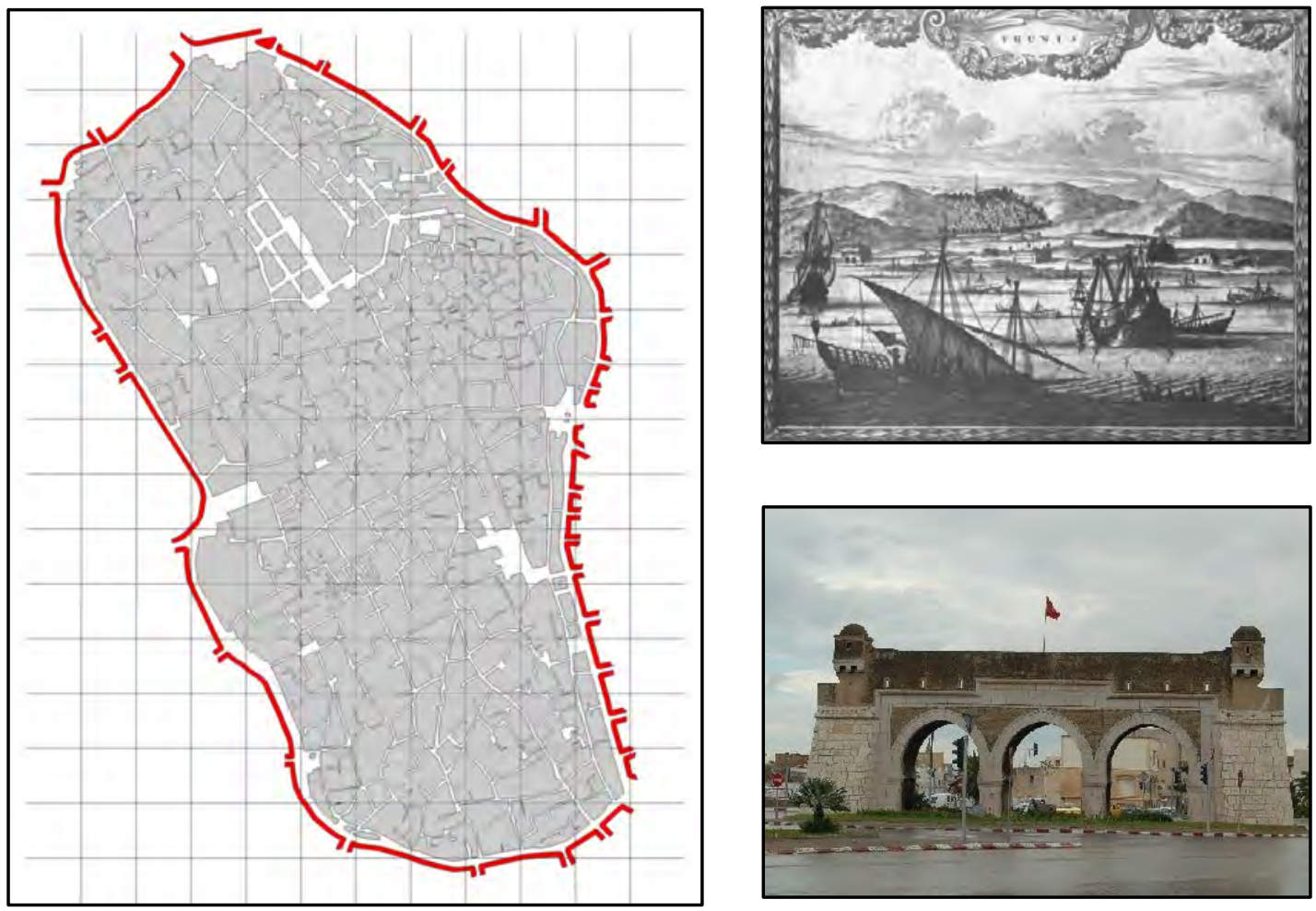

Figure 5. (Left) Tunis general layout (Source: Author, 2015); (Top Right) The city \& port of Tunis (Source: wikwand.com/fr/oire_de_tunis, 2015); (Bottom Right) Historical Gate

(Source:www.virtual Tourist.com, 2015).

Like many other traditional Arab-Muslim cities, Tunis is characterized by its compact courtyard houses, which are mostly one or two stories high. The central mosque is surrounded by several suqes (markets), making the area around the mosque the central public place, where residents meet, pray and shop. Being originally an Arab-Muslim city, the medina of Tunis can be said to be completely designed around a central mosque, Al-Zaitouna, making the commercial area concentrated around the grand mosque, where certain trades and crafts grouped together, surrounded by clusters of residential areas (Sauod, 2002). Small shops, Hammams, small mosques and bakeries are distributed within the residential areas, providing the residents with their everyday needs. Certain polluting activities such as dyeing, tanning and pottery kilns were Archnet-IJAR, Volume 10 - Issue 1 - March 2016 - (325-343) - Regular Section 
located on the edge of the city (McGuinness, 1992). It is important to note that as the city became a tourist destination and as the walls of the city no longer existed, small shops around the city perimeter started to emerge.
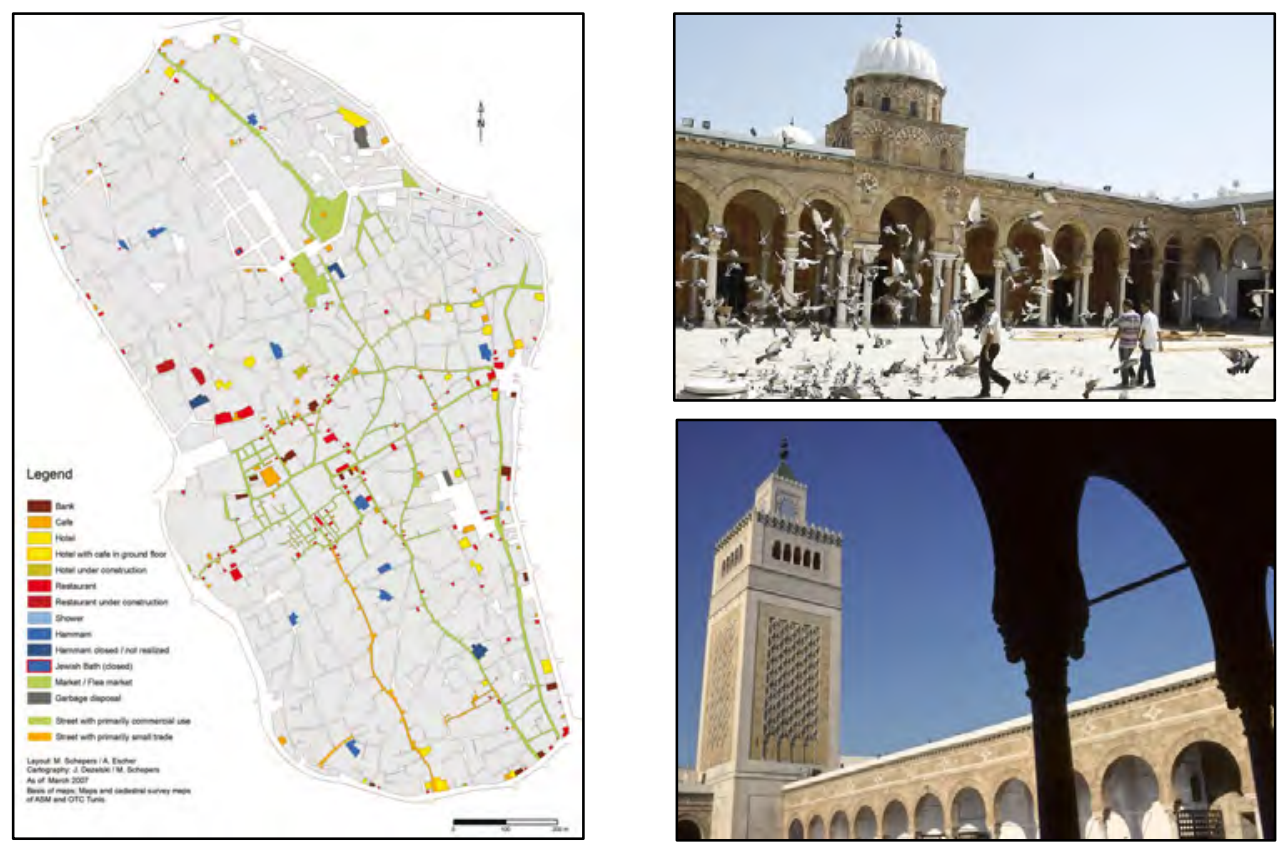

Figure 6. (Left) Land use in traditional medina of Tunis (Source: Anton Escher, 2007); (Right) Al Zaytuna Mosque (Top Source: http://www.al-monitor.com/), (Bottom Sorce: http://en.tunisientunisie.com/, 2015).

Fez:

The traditional city of Fez was originally formed as two separate towns, one on the right river bank by Idris I, and one on the left bank by his son Idris II. Each city was surrounded by a wall. Idris II encouraged immigrants from different regions to settle in his city while it was still under construction. Immigrants expelled from Cordoba in Spain occupied the right bank of Fez and constructed a mosque called the Andalusian mosque. A year later immigrants from Qayrawan in Tunis occupied the left bank, reconstructed the mosque that was originally founded in the midninth century and called it the Qarawiyyin mosque. The two towns developed separately around their great mosque until 1070, when Al-Moravids combined the two towns into one and constructed one wall around both, to further unite them. They also reconstructed the Qarawiyyin mosque and changed it into a great mosque with astonishing Andalusian ornamentation, which has been the city's landmark ever since. 


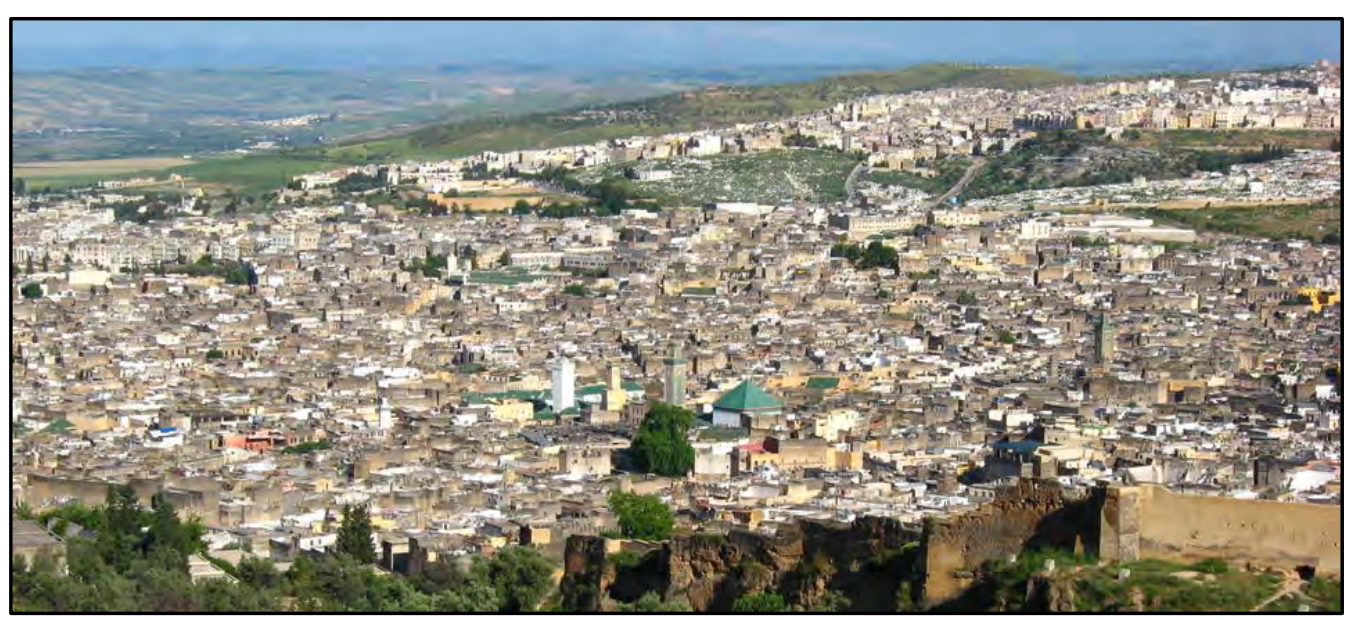

Figure 7. An overview of traditional medina of Fez (Source: www.godsmurf.com, 2015).

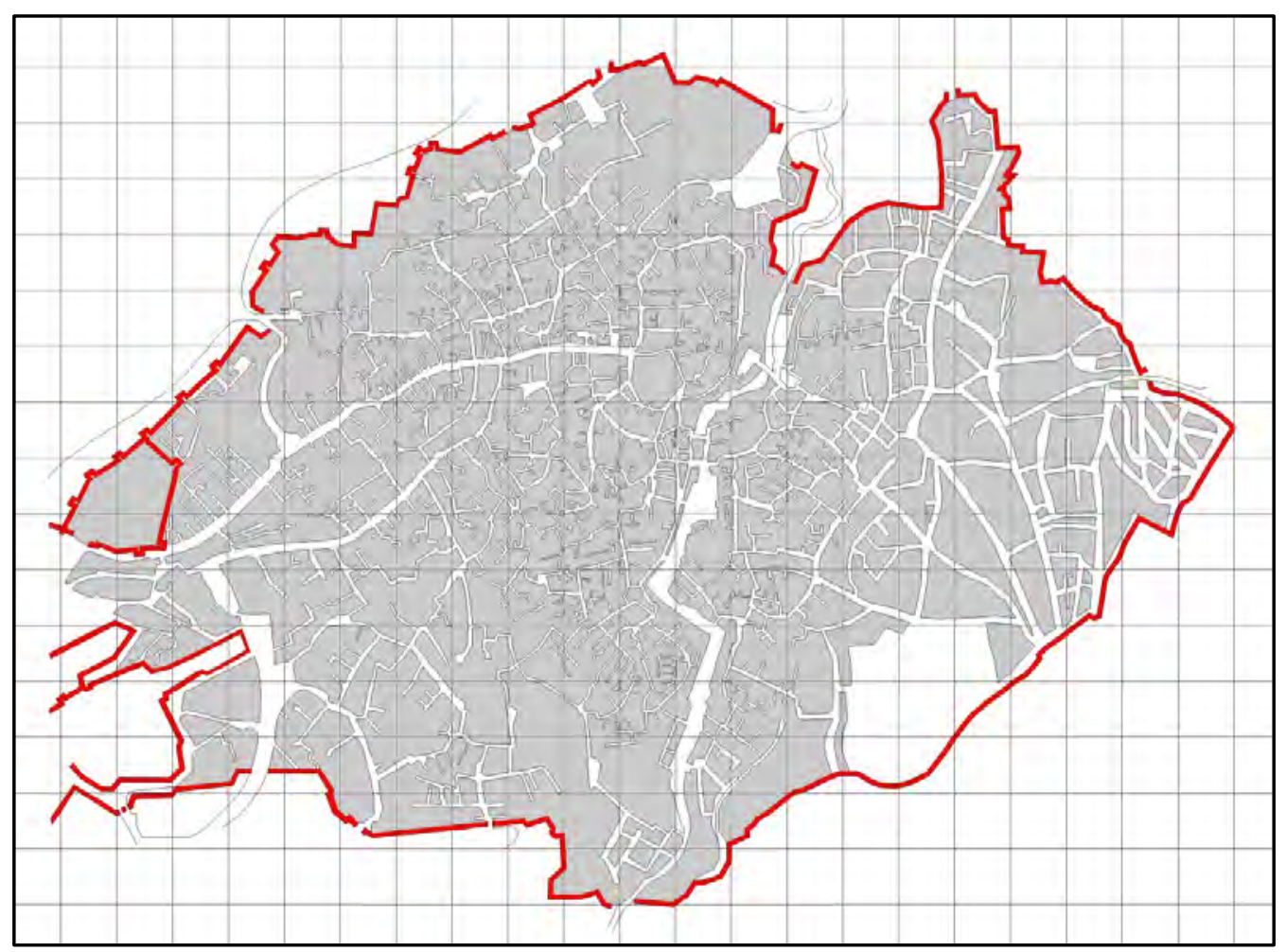

Figure 8. Fez general layout (Source: Author, 2015).

The visual form of the traditional city of Fez is dominated by its great mosques and its great walls, large portions of which still surround the present day city. The two portions of the city are separated by the river that runs between them, yet they are connected by a number of bridges. The area covered by the street network in Fez is very small compared to the area of the built fabric. Like many other Islamic cities, this street network mainly provides connections between 
the different city gates and the centre of the city, at the same time ensuring selective accessibility of the residential quarters (Bianca, 2000).
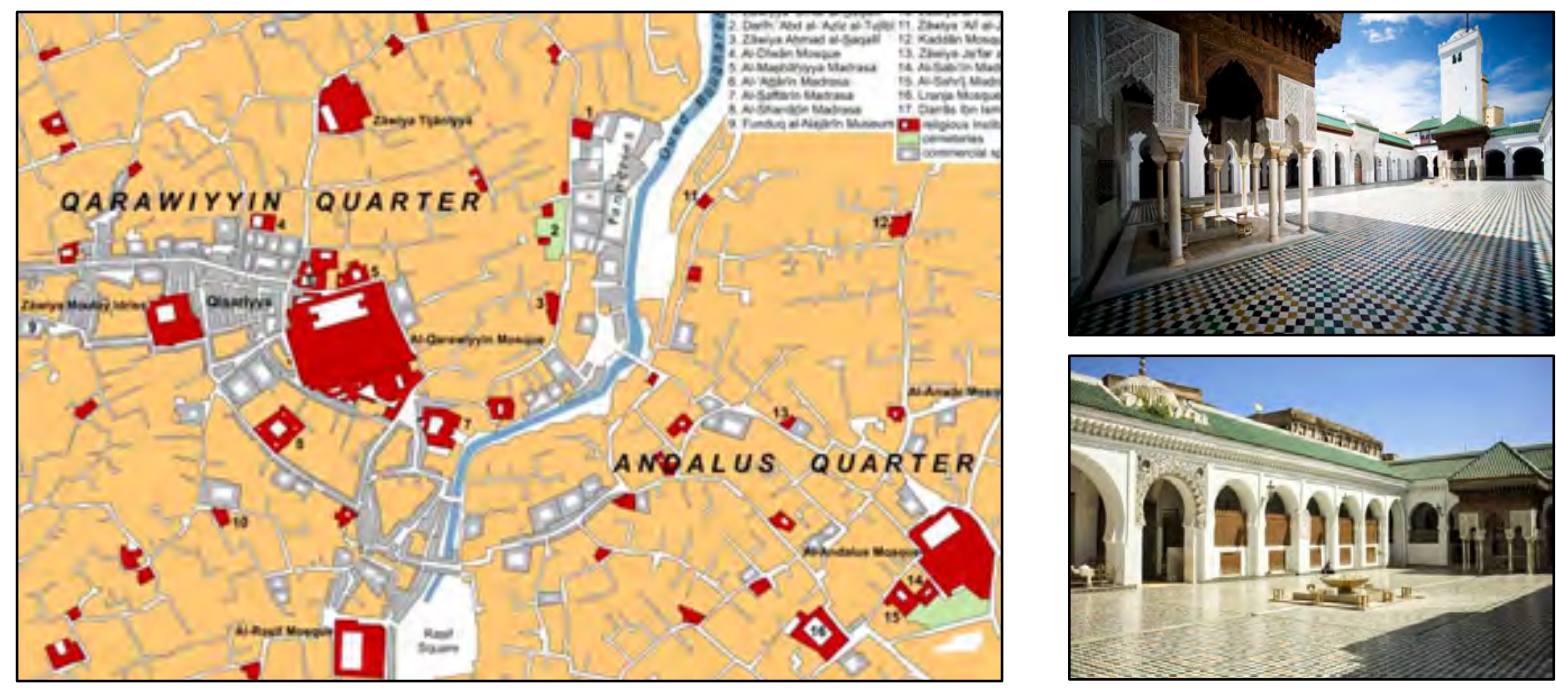

Figure 9. (Left) Land use in traditional medina of Fez (Source: www.ericrossacademic.wordpress.com, 2015); (Right) Qarawiyyin Mosque (Top Source: http://www.mithaqarrabita.ma/, 2015), (Bottom Source: www.chezmamielucette.eklablog.com/, 2015).

The compact urban structure of Fez is characterized by courtyard houses and narrow alleys. Cul-de-sacs contribute to its extensive street network. It is important to note that the irregular nature of the street network is mostly caused by the irregular, hilly topography. The city is characterized by the great contrast between the very dense fabric and the open green areas that surround its walls (Bianca, 1983).

Like many other Arabic-Muslim cities, Fez is divided into several residential quarters, each containing clusters of courtyard houses that are mostly two or three stories in height. As stated earlier, the city of Fez is mainly developed around its great mosques. Consequently, the main commercial activities are located around the great mosques, especially those of the Andalusian and the Qarawiyyin. The city also contains countless small mosques and colleges, located in different parts of the city. Small shops, bakeries and Hammams are evenly distributed within the residential quarters. The separation between public and private domain, the interaction of public space and the volumetric articulation of space, which are basic Islamic structuring principles, are rigorously maintained in the medina of Fez (Bianca \& Katz, 1980). Significantly, the Qarawiyyin quarter contains more commercial activities than that on the right bank of the river.

\section{LESSONS LEARNED:}

The three cities of Tripoli, Tunis and Fez exhibit many similar urban characteristics. However, each has certain features that make it unique; this uniqueness is caused by a natural setting that affected its urban pattern, historical foundations that affected its original layout, or indeed by an evolution over time that made it transform and develop differently.

\section{Current State:}

Due to both the formation of new colonial cities, and the deterioration of traditional cities, many locals left traditional cities looking for a better living standard. Following Libya's independence and the discovery of oil, and the departure of Italians and British from Libya, many rich families 
abandoned the old medina and moved into newly built colonial quarters. Some people left mainly because of the deterioration of the old medina, while others viewed living in the garden city as a sign of social promotion. This turned the traditional city into a place for the less fortunate and nonskilled immigrants. Today, the old Medina of Tripoli is still surrounded by some remaining portions of its great walls on the north, west and south-eastern borders. The Castle, with its hanging garden, dominates the south-east corner of the city. Despite some restoration works undertaken by the Libyan government, the old medina of Tripoli is facing great challenges caused by poor maintenance, lack of adequate infrastructure and overcrowding. In adopting a selective approach to heritage conservation, most of the restoration works are focused on important historical buildings or certain tourist areas, rather than on the whole urban fabric of the old medina.

The old medina of Tunis slowly began to lose its importance due to the domination of the newly-built French city. Many wealthy Tunisian families left the medina in favour of the fancy modern villas that were built around the colonial city. This exodus of the rich increased after independence in 1956 and the massive departure of the European population. The traditional city of Tunis is now listed as a world heritage site but, despite some rehabilitation and renovation attempts, such that of the Hafsia quarter, some Tunisians believe that the public authorities have been unable to halt the decline of the old medina.

When Morocco gained its independence in 1956, the Moroccan royal family started various restoration programs, which consequently led to the recognition of $\mathrm{Fez}$ as a universal heritage to be preserved. In 2000 the Moroccan government adopted a development plan for Fez, which was to be re-evaluated every ten years, and undertook certain measures to safeguard the city. Despite the number of families that left the old medina in search of better living, and the poor condition of some areas that are in great need of restoration, Fez is without doubt one of the best preserved medieval cities in the world.

In general, and despite the renovation and maintenance efforts applied to traditional medinas of Tripoli, Tunis and Fez, the cities are dealt with today as if they were dead artefacts rather than living entities. The renovation and rehabilitation works vary from one city to another, yet they all face similar problems and challenges.

\section{Visual Form:}

The visual form of the cities is usually dominated by great buildings. Sometimes the great building is in the form of a great mosque that is located in a central location within the city, as with Al Zaituna mosque in Tunis and Qarawiyyin mosque in Fez. At other times the great building represents a governmental palace or a fortress, as Al Saraya Al Hamra palace in Tripoli. The three cities were originally surrounded by great walls containing a number of gates, which through time become original features of the cityscape. However, the walls are partly demolished, as is the case in Tripoli, where certain portions were demolished during the Italian colonization, or completely demolished apart from major gates, as in Tunis, where the walls were replaced by a ring road during the French colonial era, or are mostly preserved, as in Fez.

It is important to note that Fez benefited from continuous evolution compared to Tripoli and Tunis, as its rulers were more interested in competing with their predecessors through erecting new architectural works, rather than destroying previous works. Tunis was demolished alongside Carthage by the Romans after the 3rd Punic war, and Tripoli is believed to have been completely destroyed, apart from the castle and the defensive wall, by the Spanish in 1509. This might explain the richness and the size of Fez compared to the other two cities, which were both to be reconstructed in a certain point in their history. The three cities are characterised by a clear consistency in building heights, but, while houses in Tripoli and Tunis are mostly one and two stories high, the houses in Fez mostly exceed two stories. 
Table 2: Main Buildings \& State of Defensive Wall (Source: Author, 2015).

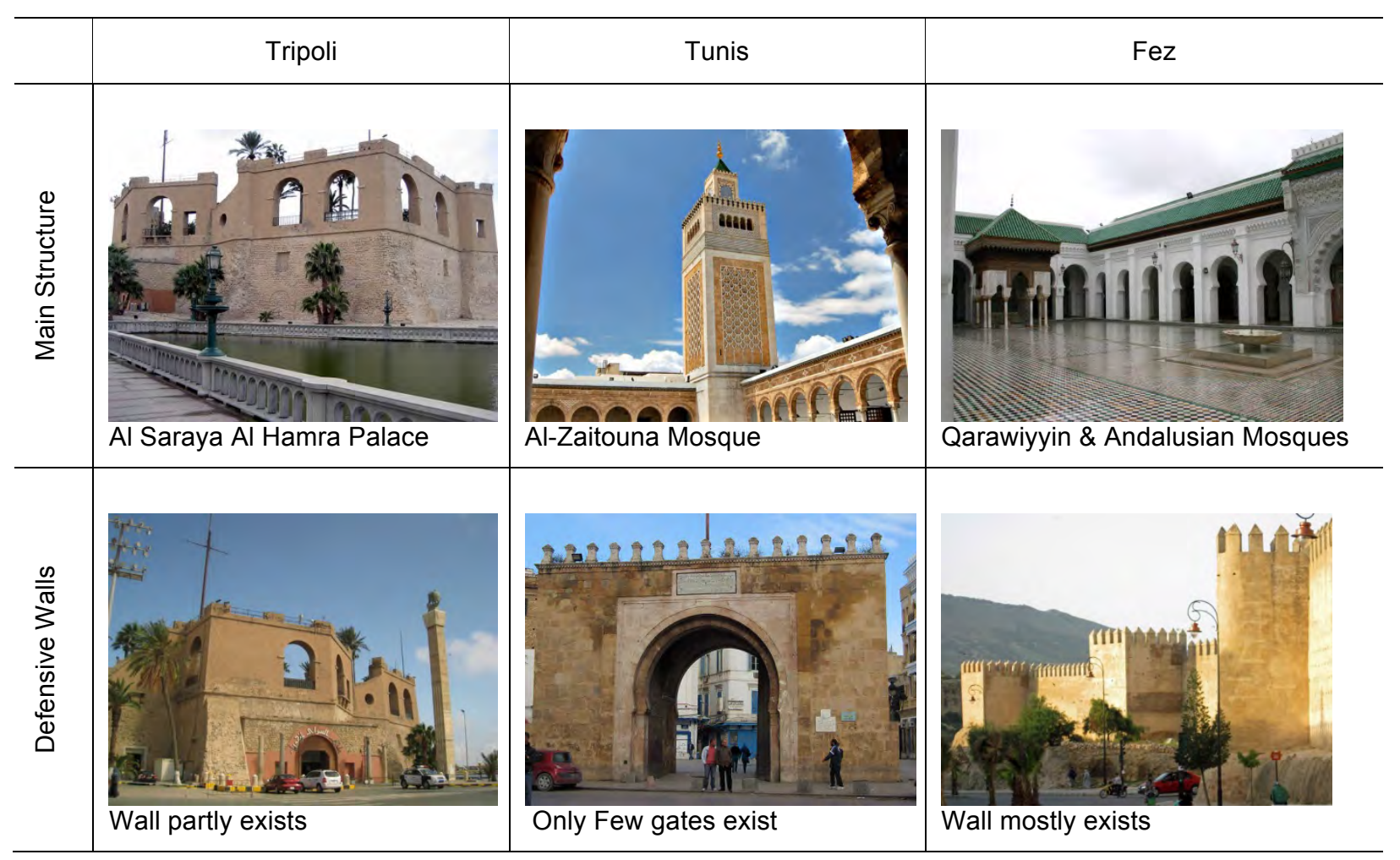

\section{Urban Pattern:}

The three cities are characterized by compact urban fabric made of courtyard houses and narrow alleys. The size of the urban plots in the three cities is relatively large, containing a number of cul-de-sacs, in order to provide access to the internal area of the blocks. Friedrich Ragette (2003) describes the street network in traditional medinas as a living organism, where streets branch out from a central place to become lanes and narrow alleys and finally come to a dead end. Although the street network is made up of main streets, connecting streets and cul-de-sacs, the main streets' pattern and connecting points vary from one city to another. Sometimes the main streets follow original roman roads (cardo and decumanus), as in Tripoli. At other times the main streets serve to connect the different city gates and to connect the gates with central mosques, as in Tunis and Fez.

The urban fabric of the three cities clearly reflects the concept of social solidarity or Ummah, in which religious beliefs and values, especially those relating to organization and authority, encourage social interaction and discourage dispersal (Saoud, 2002). This can easily be seen in the residential clusters, which each contains a variety of house sizes where rich and poor families live next to each other without any division. Other public areas in Islamic towns are cafés, and hammams or public baths. As these places, together with small mosques and markets, are dominated by men, there is a great emphasis on accessibility and unrestricted contact. The access to residential quarters from public areas is usually broken into successive sections hierarchically, indicating increasing degrees of privacy. The houses are not directly exposed to the external world, as circulation is gradually filtered by different intermediate sections of the street network, providing a great degree of protection, and preserving the privacy of the family sphere (Bianca, 1981). 
Table 3: Urban Pattern of the three cities (Source: Author, 2015).

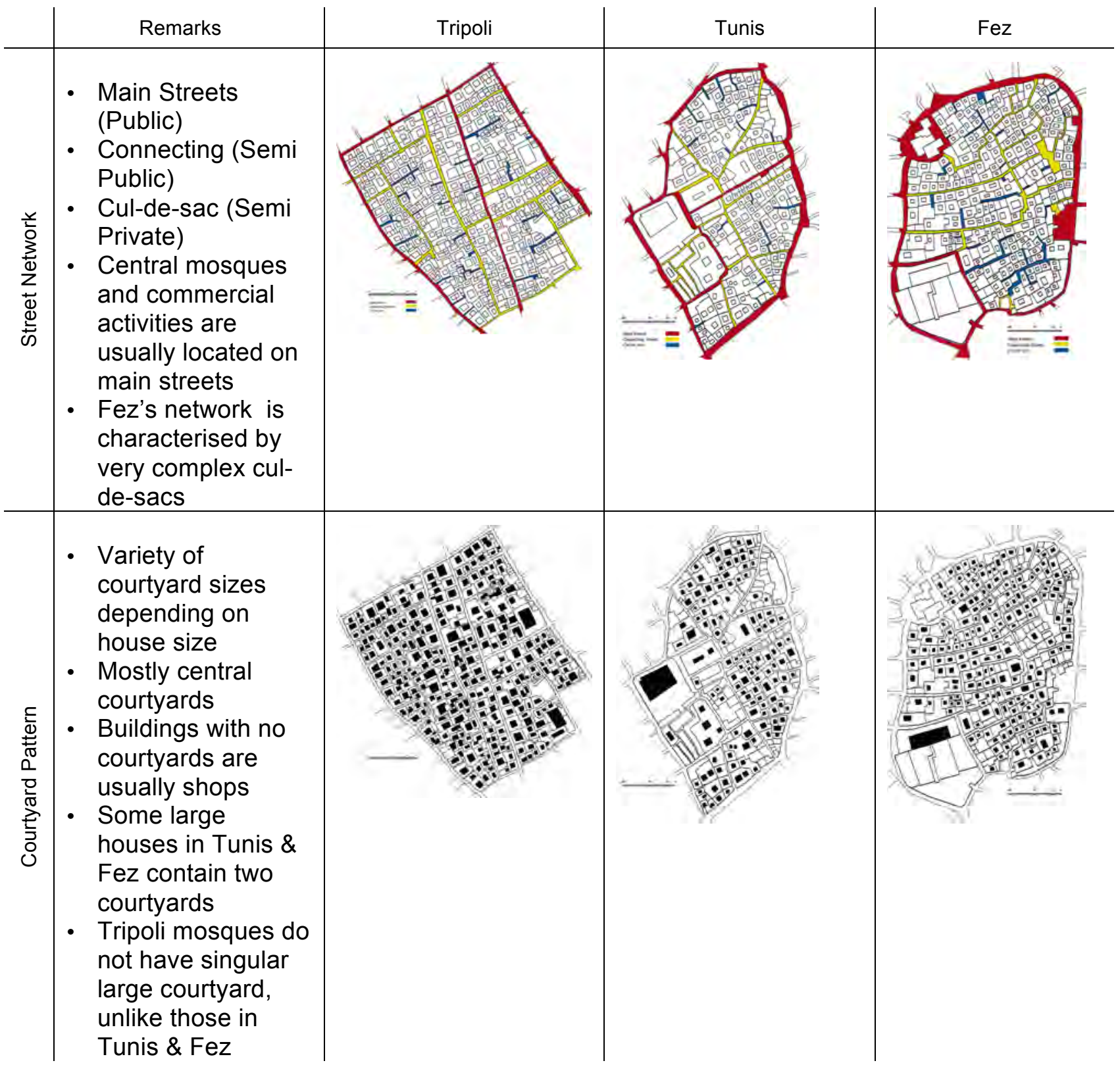




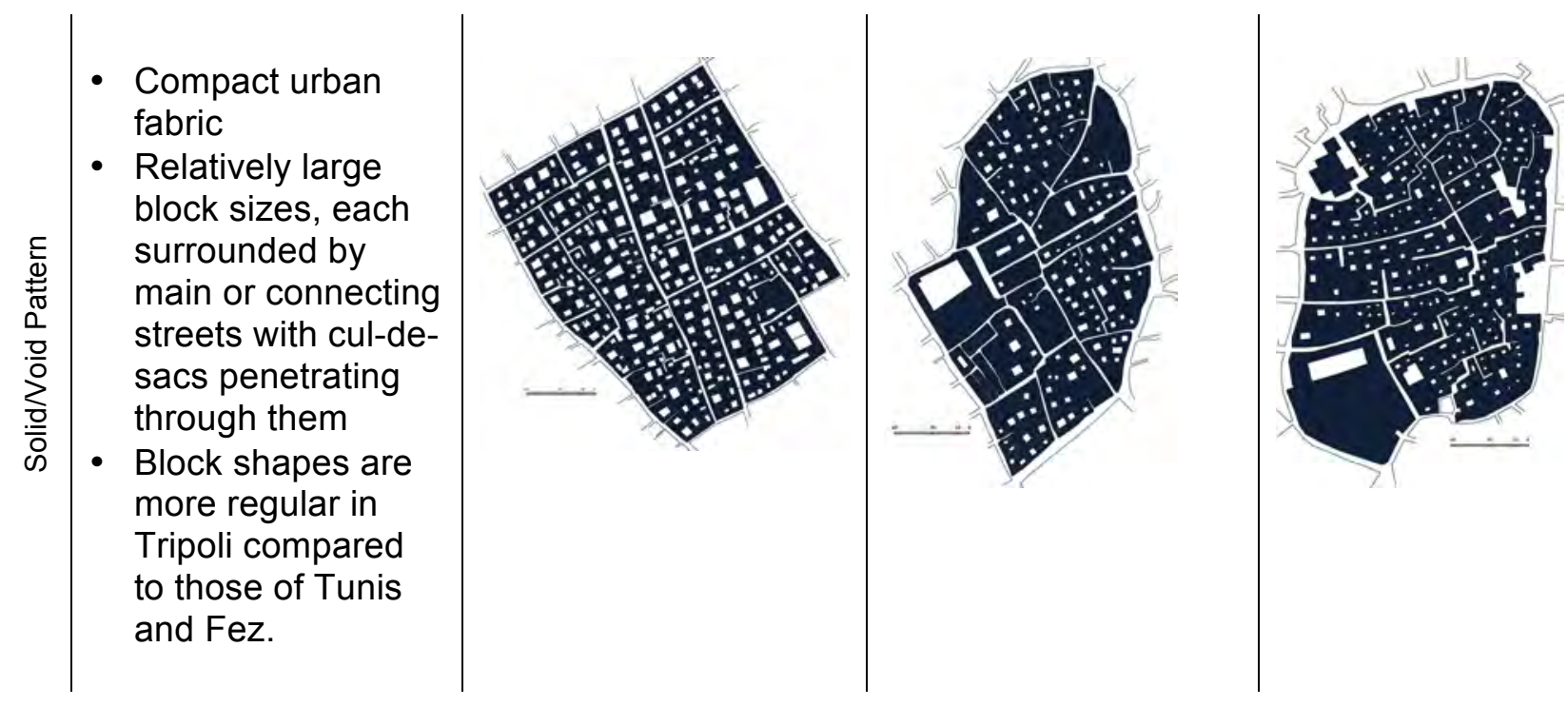

\section{Land Use:}

In the three cities commercial centres mostly surround the big mosques in the city. The central mosque usually intends to serve several quarters or even the whole town on Fridays and on feasts (Ragette, 2003). Despite the absence of a central mosque in Tripoli, commercial activities are concentrated in the eastern south corner of the city, where most of the big mosques are located. In Tunis the main commercial activities surround the great mosque of Al-Zaytuna and in Fez they surround Qarawiyyin Mosque.

Table 4: Land Use (Source: Author, 2015).

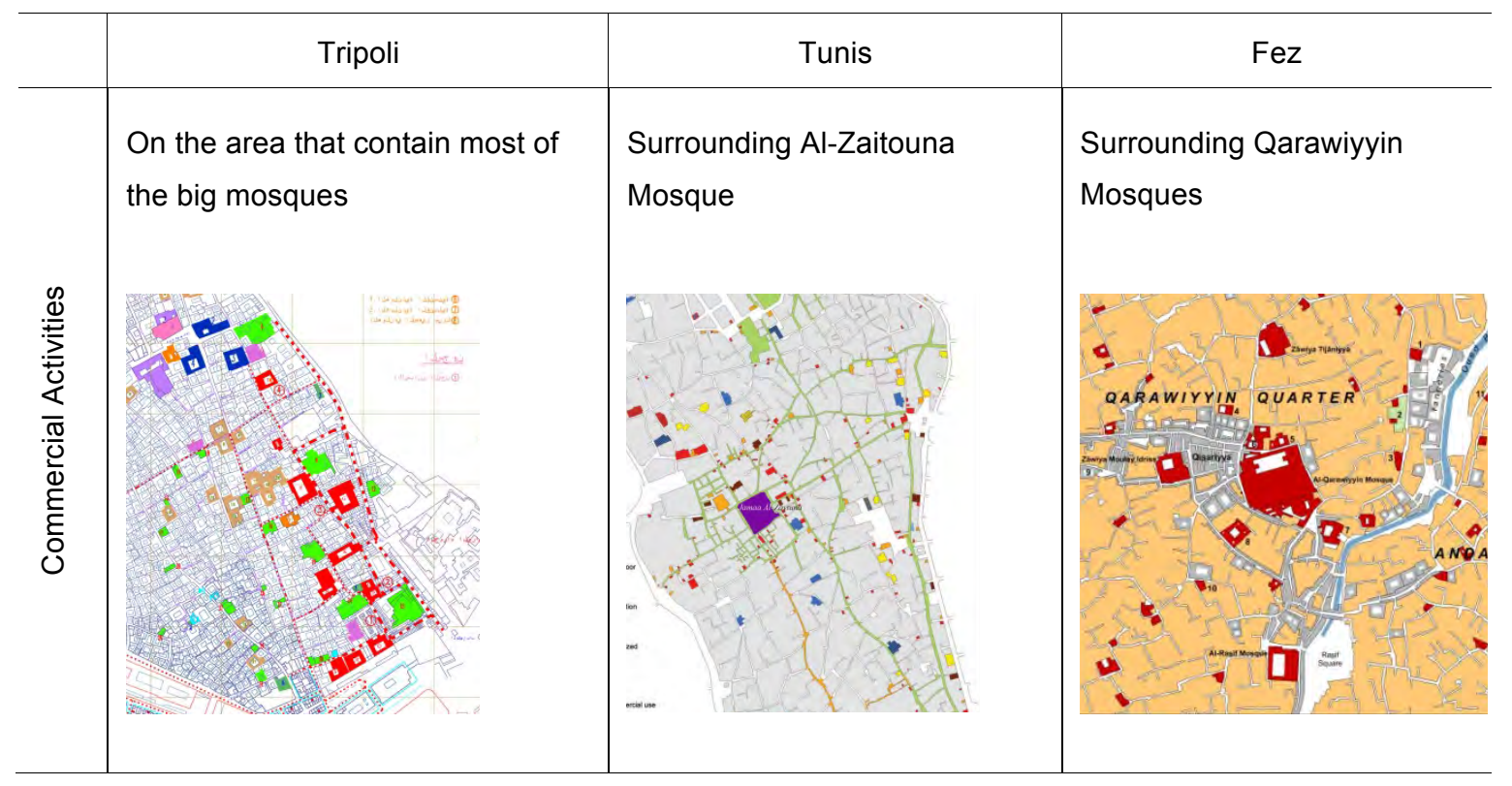


As in many other cities in the Muslim world, the distribution of land uses in the traditional environment of the three cities is always seen as a mixed-pattern, emphasising social integration. Yet, there is a certain degree of separation between public and private realms, which reflects the Islamic concern for privacy in residential quarters.

Tripoli, Tunis and Fez characteristically comprise a tripartite system of public, semi-public and private spaces, with various degrees of accessibility and enclosure. The mosque, being the main public core, is usually embraced by markets, forming a coherent architectural complex (Bianca, 1981). The quarters were formed by homogenous communities bound by common religious, ethnic or social ties, providing a strong social identity and security. However, a balance was always maintained between the social self-sufficiency of the quarter and its participation in the communal affairs of the city as a whole (Petherbridge, 1978). Areas around big mosques in the three cities still form, today, active commercial areas and still preserve their function as public gathering spaces.

\section{CONCLUSION}

The traditional medinas of Tripoli, Tunis and Fez have a rich and complex urban fabric that reflects the history of each city, and which has developed over time. It is state by Besim Hakim (2008, p13 ) that Arabic Islamic cities in the Maghrib, especially those founded by Arabic Muslim leaders were the purest in terms of their general Islamic framework and their specific Arabic attributes. The contextual characteristics of these cities, therefore, provide us with valid lessons that can contribute to improving the quality of the contemporary built environment in the Arabic Islamic cities, and safeguard the city's historical and cultural identity, which is in danger of being totally lost. Culture heritage should be understood, protected and enriched, since without history and memory the present is devoid of context: it exists more or less in a vacuum (Rghei \& Nelson, 1994, p143).

In the analyses of the traditional medinas it is evident that religious values were greatly reflected in the urban form, especially those relating to social solidarity and privacy. Although today's life style is different from that of tradition, most of the people in the three cities, especially those of Tripoli and Fez, are still greatly guided by religious values. Maintaining social solidarity and privacy within the built form is, therefore, essential when creating contemporary projects in these cities. The visual form of these traditional cities clearly reflects their history and rich heritage. Tradition in these cities is a multi-layered complex that evolved over centuries, and which should be studies, preserved and enhanced in contemporary planning policies and design practice. Lessons obtained from the visual form of traditional medina do not necessarily require the adoption of the exact traditional architectural forms, but the recognition of the way in which these forms reflected the people's cultural identity and responded to their social and religious values.

Compact urban fabric with the use of the courtyard concept proved to be ideal in enhancing social solidarity as well as limiting solar heat absorbed by building surfaces. However, compactness and the reuse of the courtyard concept should be developed in a way that meets today's needs, and benefits from modern materials and technology. The street network should always maintain the aspect of main (public), connecting (semi-public), and cul-de-sacs (semiprivate), with large public buildings located on main and connecting roads, and cul-de-sacs being mainly residential. Yet, with automobiles being an essential part of life today, considerable thinking should be put into providing appropriate solutions for parking and movement routes. The urban pattern of traditional medinas is a direct response to two main principles of the people who lived in them, which are social solidarity and privacy. Social solidarity is manifested through three concepts. First is a variety of plot sizes in order to meet different financial abilities within the same residential cluster, allowing social integration between rich and poor. The second is the use Archnet-IJAR, Volume 10 - Issue 1 - March 2016 - (325-343) - Regular Section 
of the cul-de-sac, which enhances neighbour relations by acting as a semi- private meeting space for those who live on it. Finally, there is the distribution of small mosques throughout the residential quarters, which provides public spaces within walking distance for residents to meet for daily prayers. Privacy, on the other hand, is manifested through the use of the courtyard concept, which provides a high degree of privacy for houses, and the range of street types, where privacy degree varies depending on the street type. These principles should be taken into consideration when designing contemporary urban patterns, not only because they respond to social requirements, but also because they can support the interrelation between decision makers and society.

Land-use in the contemporary built environment should provide people with everyday needs within walking distance of their homes. Distributing small mosques, bakeries and small shops within walking distance will automatically encourage people to walk and consequently encourage social interaction. However, this should be done in a way that preserves the privacy degree required in residential quarters. Many argue that the gap between decision makers and users is a major cause of people's dissatisfaction in our contemporary urban environment. Therefore, designing contemporary urban patterns that provide residents with easy access to everyday requirements, and respond to their social and religious values, can help decision makers and designers to realign with their own people, and regain their trust.

The medina of Tripoli, Tunis and Fez all represent traditional Islamic cities that have gone through cycles of development and transformation, yet they have always maintained a sense of continuity throughout their history. Direct copying from traditional Islamic medinas, however, is not an option, as this will only create an urban fabric that is neither Islamic in character, nor contemporary in technology. The real challenge for decision makers and designers is finding the way to practically manifest the essence of traditional medinas in an urban environment dominated by automobiles, and new forms of urbanisation in societies that are suffering greatly from fractured identity. The big question is whether or not they are willing to take that challenge.

\section{ACKNOWLEDGEMENT}

The work presented here is part of ongoing PhD research at The University of Strathclyde. The author would like to thank her supervisor, Prof. Ashraf Salama, for his helpful and valuable comments on improving this study.

\section{REFERENCES}

Al-Lahham, A. (2014). Traditionalism or Traditiona-lieism: Authentication or Fabrication? Archnet-IJAR, Volume 8 - Issue 3 - November 2014 - (64-73)

Amodei, M. (1985). Tunis 1860-1930: The Formation of a Colonial Town, http://archnet.org/ system/publications/contents/3180/original/DPC0670.pdf?1384773800, Access date 2015.

Bianca, S. \& Katz, J. (1980). Fez: The Ideal and the Reality of the Islamic City, http://archnet.org/ system/publications/contents/2634/original/DPC0103.pdf?1384766724, Access date 2015.

Bianca, S. (1981). Traditional Muslim Cities \& Western Planning Ideology, cited in Mortada, H. (2003) Traditional Islamic Principles of Built Environment, Routledge Curzon, London

Bianca, S. (1983). Conservation and Rehabilitation Projects for the Old City of Fez, http://archnet.org/ system/publications/contents/3069/original/DPC0373.pdf?1384770818, Access date 2015.

Bianca, S. (2000). Urban Form in the Arab World, Thames \& Hudson.

Bosworth, C. (2010). Historic Cities of the Islamic World, Brill

Brolin, B. (1976). The Failure of Modern Architecture, Van Nonhold Co.

Eikelman, D. (1981). The Middle East: An Anthropological Approach, Prentice Hall New Jersey

Hakim, B. (2008). Arabic-Islamic Cities: Building and Planning Principles, Emergent City Press 


\section{ArchNet}

McGuinness, J. (1992). The Development of Conservation Management for a Pre-Industrial North African City: The Case of the Medina of Tunis, unpublished M.A. thesis, http://etheses.dur.ac.uk/, Access date 2015.

McKenna, A. (2011). The History of Northern Africa, Rosen Education Service

McLaren, B. (2006). Architecture \& Tourism in Italian Colonial Libya: An Ambivalent Modernism, University of Washington Press, Washington

Metz, H. (2004). Libya, Kessinger Publishing, LLC

Micara, L. (2008) The Ottoman Tripoli: a Mediterranean Medina. In Jayyusi, S.K et al. (eds), The City in the Islamic World. Brill-Holland, pp. 383-406.

Micara, L. (2013). Tripoli: A Mediterranean Medina, Gangemi Editor, Rome

Petherbridge, G. (1995). The House and Society, in Michell, G (1995). Architecture of the Islamic World: Its History and Social Meaning, Thames \& Hudson Ltd, London

Remali, A. et al (2015), Street Quality, Street Life, Street Centrality. In, Vaughan, L (eds), Suburban Urbanities. UCL Press, pp.104-129.

Rghei, A. \& Nelson, J. (1994). The Conservation and Use of the Walled City of Tripoli, The Geographical Journal, Vol. 160 (2), 143-158.

Ragette, F. (2003). Traditional Domestic Architecture of the Arab Region, Edition Axel Menges.

Saidi, H. (2011). Capital Cities as Open-Air Museums: a look at Quebec City and Tunis, Current Issues in Tourism, 15:1-2, 75-88, DOI: 10.1080/13683500.2011.634896, Access date 2015.

Saoud, R. (2002). Introduction to the Islamic City, FSTC Limited

Sibley, M. \& Fadli, F. (2008). The Surviving Historic Hammams of the Medina of Tripoli - Libya: Tangible and Intangible Dimensions, Archnet-IJAR, Volume 2 - Issue 3 -November 2008- (93-108)

Warmington, B. (2015), North Africa, www.britannica.com/place/North Africa, Access date 2015.

Wright, J. (1969). Libya: Nations of the Modern World, Ernest Benn Ltd

\section{AUTHOR}

Huyam H. Abudib

PhD Candidate - The University of Strathclyde, Glasgow, UK

huyam.abudib@strath.ac.uk 